\title{
Varying effects of an IUD on decidualization in mice
}

\author{
L. Martin and C. A. Finn* \\ Department of Hormone Physiology, The Endocrine Group, Imperial Cancer Research Fund, \\ Lincoln's Inn Fields, London WC2A 3PX, and * Department of Physiology, Royal Veterinary' \\ College, London NW1 OTU, U.K.
}

\begin{abstract}
Summary. Chronically implanted IUDs consisting of silk suture threads induced decidualization in regions of the uterus remote from the suture site in ovariectomized mice treated with a regimen of progesterone and oestrogen which sensitizes the uterus to a decidual stimulus. In these conditions the IUDs did not inhibit decidualization induced by instilled oil, although they did so in pregnant animals of the same strain. Varying the dose of progesterone and oestrogen did not produce conditions in which IUDs inhibited oil-induced decidualization in ovariectomized mice and progesterone treatment did not prevent IUDs inhibiting decidualization in pregnant animals. However, when ovariectomized mice, sensitized as before, were primed repeatedly with oestrogen to simulate continuing oestrous cycles after IUD insertion, the IUDs inhibited oil-induced decidualization. This involved the premature loss of instilled oil from the uterine lumen and was associated with heavy infiltration of leucocytes into the luminal epithelium. Numbers of leucocytes free in the uterine lumen did not appear to be critical. It appears that contact between the oil and the luminal epithelial surface must be sustained for some length of time to induce a decidual reaction; brief contact is not sufficient to trigger the response.
\end{abstract}

\section{Introduction}

Kar, Goswami, Kamboj \& Chowdhury (1964) and Brown-Grant (1969) suggested that intrauterine devices are contraceptive in rodents because they increase the sensitivity of the uterus to oestrogen. Intrauterine sutures induce luminal epithelial hypertrophy and increase luminal and glandular epithelial mitosis in otherwise untreated ovariectomized mice, while in progesterone-treated ovariectomized mice they increase stromal mitosis and deplete luminal epithelial lipid (Martin \& Finn, 1978). Many of these effects resemble those produced by oestrogen (Martin, Finn \& Trinder, 1973a, b).

The induction of decidualization by intraluminal oil in mice requires pretreatment with a small amount of oestrogen as well as a large amount of progesterone (Finn, 1965; Finn \& Martin, 1972; Martin, 1977). The present experiments were initiated to determine whether the presence of an IUD would obviate the need for oestrogen in the induction of decidualization by oil.

\section{Materials and General Methods}

Randomly bred Swiss albino mice were housed at $21^{\circ} \mathrm{C}$ with lights on from 06:00 to 18:00 h. The details of the methods for each experiment are given in the 'Results'. All surgery was carried out using tribromoethanol (Avertin: Winthrop) anaesthesia. The IUDs, consisting of silk suture

\footnotetext{
* Present address: Department of Veterinary Physiology, University of Liverpool. Leahurst, Neston, Wirral, Merseyside, L64 7TE, U.K.
} 
threads, were inserted when the animals were 6-8 weeks old. Usually a single thread was inserted, via a dorsal incision in the body wall, through the antimesometrial wall of the anterior tip of the left uterine horn immediately below the uterotubal junction (i.e. the 'ovarian' end), as described by Martin \& Finn (1970, 1978). In some animals (Exp. 3) the thread was placed antimesometrially in the left uterine horn 3-4 mm anterior to the cervix via a mid-ventral incision ('cervical'). Control animals without IUDs were sham operated. Ovariectomy, when performed, was carried out at the same time as IUD insertion or sham operation. Injections of oestradiol$17 \beta$ (B.D.H.) and progesterone (B.D.H.) were given subcutaneously in $0.05 \mathrm{ml}$ arachis oil.

The instillation of arachis oil $(5-10 \mu l)$ was made via an incision in the dorsal body wall through the anterior tip of the left uterine horn, as were sham instillations. The right horn was left untreated as a control. Thus in uteri with IUDs the point of oil instillation corresponded to the point of insertion of the silk thread. After instillation, oil is distributed throughout the instilled horn and in suitably sensitized organs induces decidualization along the length of that horn. In animals treated with progesterone alone the instilled oil does not induce decidualization and responses arise from the trauma of instillation and are restricted to the tip of the horn (Finn, 1965). It is important, therefore, to distinguish decidual responses limited to the site of oil instillation and IUD insertion from those in regions of the uterus remote from this site.

At autopsy the distribution of decidual responses was noted. Control and treated uterine horns were separated and weighed. The silk threads were left in situ because their weights were negligible. The difference between the weights of the treated and untreated horns was taken as the weight of the decidual tissue in the treated horn (Finn, 1965). For histology, uteri were fixed in Bouin's fluid and $5 \mu \mathrm{m}$ paraffin wax sections were stained with Cole's haematoxylin and eosin. All putative decidual responses were confirmed by examination of histological sections. Leucocytes in histological sections were counted as described by Martin \& Finn (1970).

\section{Results}

\section{Experiment 1: effects of IUDs on oil-induced decidualization}

Ovariectomized females were left untreated for 2 weeks and then primed once with a series of 3 once-daily subcutaneous injections of $100 \mathrm{ng}$ oestradiol-17 (Finn \& Martin, 1972). Starting on the 3rd day after the last priming injection, progesterone $(1 \mathrm{mg})$ or progesterone $(1 \mathrm{mg})$ plus oestradiol-17ß (10 ng) were given at 11:00 h daily for 3 days. Intrauterine instillation of oil or sham instillation was carried out at $14: 00 \mathrm{~h}$ on the $3 \mathrm{rd}$ day, when sensitivity to a deciduainducing stimulus is known to be maximal (Finn \& Martin, 1969, 1972).

Table 1. The effects of an IUD (in the ovarian tip of the horn) on decidualization in primed ovariecto mized mice treated with progesterone $[P]$ and oestradiol $-17 \beta\left(\mathrm{Oe}_{2}\right)$

\begin{tabular}{|c|c|c|c|c|c|c|}
\hline \multirow[b]{3}{*}{$\begin{array}{l}\text { Hormone } \\
\text { treatment }\end{array}$} & \multirow[b]{3}{*}{$\begin{array}{l}\text { Material } \\
\text { instilled }\end{array}$} & \multirow[b]{3}{*}{ IUD } & \multirow[b]{3}{*}{$\begin{array}{l}\text { No. of } \\
\text { mice }\end{array}$} & \multicolumn{3}{|c|}{ Decidual response } \\
\hline & & & & & \multicolumn{2}{|c|}{ No. of horns positive } \\
\hline & & & & $\begin{array}{l}\text { Mean } \pm \text { s.e.m. } \\
\text { wt }(\mathrm{mg})\end{array}$ & $\begin{array}{c}\text { At } \\
\text { ovarian } \\
\text { tip }\end{array}$ & Elsewhere \\
\hline$P$ & None & None & 10 & 0 & 0 & 0 \\
\hline $\mathrm{P}$ & Oil & None & 11 & $12 \pm 2$ & 3 & 0 \\
\hline $\mathbf{P}$ & None & Present & 10 & $30 \pm 6$ & 4 & 0 \\
\hline $\mathbf{P}$ & Oil & Present & 11 & $46 \pm 6$ & 8 & 1 \\
\hline $\mathrm{P}+\mathrm{Oe}_{2}$ & None & None & 11 & $\overline{0}$ & 0 & 0 \\
\hline $\mathrm{P}+\mathrm{Oe}_{2}$ & Oil & None & 11 & $127 \pm 12$ & 11 & 11 \\
\hline $\mathrm{P}+\mathrm{Oe}_{2}$ & None & Present & 18 & $61 \pm 8$ & 10 & 12 \\
\hline $\mathrm{P}+\mathrm{Oe}_{2}$ & Oil & Present & 11 & $147 \pm 20$ & 10 & 11 \\
\hline
\end{tabular}


The results in Table 1 show that, in mice given progesterone alone, decidual responses were restricted to the site of insertion of the IUD and to the site of oil instillation. Even in uteri bearing IUDs, oil instillation induced only one small decidual reaction away from the instillation site. Therefore, although many of the effects of IUDs on remote regions of the uterus resemble those produced by oestrogens, they are not functionally equivalent and do not sensitize the uterus to a decidua-inducing stimulus like oil. In mice treated with progesterone plus oestrogen, oil induced decidualization at and away from the instillation site. However, the IUDs not only failed to inhibit this response but also themselves induced decidualization in regions of the uterus remote from the IUD insertion site in $60 \%$ of mice, although never in the contralateral horn.

\section{Experiment 2: effects of varying the hormone dose levels}

Many workers have reported that in intact mated animals the presence of an IUD inhibits the decidual reaction whether it is induced by oil, histamine, trauma or acutely placed sutures (Margolis \& Doyle, 1964; Bartke, 1968; Marston \& Kelly, 1969a, b). We have shown that oestrogen and progesterone treatment reduces the leucocytosis induced by IUDs in mice (Martin \& Finn, 1978). Since leucocytosis has been implicated in IUD action the unexpected failure to inhibit decidualization in Exp. 1 might have been due to hormonal suppression of leucocytosis to below a critical level. Accordingly, two experiments were carried out in which oil was instilled into uteri with or without IUDs (see Exp. 1) and the doses of oestrogen and progesterone were varied as indicated in Table 2; the animals were primed only once with oestradiol as described for Exp. 1. The animals were killed $44 \mathrm{~h}$ after instillation of oil.

In Exps $2 a$ and $2 b$, the proportion of uteri with positive decidual responses was lower in IUD-bearing uteri than in controls but there was no tendency for the difference to increase at the lower hormone doses or to decrease at the higher. The greatest difference was obtained in Exp. $2 \mathrm{~b}$ with $1000 \mu \mathrm{g}$ progesterone and $10 \mathrm{ng}$ oestradiol, when all control uteri showed positive responses against $60 \%$ of IUD-bearing uteri. However, the mean decidual weight in the latter (including non-responders) was higher than that of the control group. This was true for all the hormone combinations in this experiment.

In Exp. $2 \mathrm{a}$ in which the progesterone dose was varied, the mean decidual weights were less in the IUD-containing horns than in the control horns but the differences were not significant $(P>$ $0.05 ; t$ test). At no dose combination did IUDs completely inhibit decidualization.

Table 2. The effects of different hormone doses on decidual responses away from the site of IUD insertion or oil instillation in ovariectomized mice with and without IUDs

\begin{tabular}{|c|c|c|c|c|c|c|c|}
\hline & & \multicolumn{3}{|c|}{ Without IUD } & \multicolumn{3}{|c|}{ With IUD } \\
\hline \multirow{2}{*}{\multicolumn{2}{|c|}{ Hormone dose }} & \multirow[b]{3}{*}{$\begin{array}{l}\text { No. of } \\
\text { mice }\end{array}$} & \multicolumn{2}{|c|}{ Decidual response } & \multirow[b]{3}{*}{$\begin{array}{l}\text { No. of } \\
\text { mice }\end{array}$} & \multicolumn{2}{|c|}{ Decidual response } \\
\hline & & & Mean $t$ & & & Mean + & \\
\hline $\begin{array}{c}\text { Progesterone } \\
(\mu \mathrm{g})\end{array}$ & $\begin{array}{l}\text { Oestrogen } \\
\text { (ng) }\end{array}$ & & $\begin{array}{c}\text { s.e.m. } \\
\text { wt (mg) }\end{array}$ & $\begin{array}{l}\text { No. } \\
(\%)\end{array}$ & & $\begin{array}{l}\text { s.e.m. } \\
\text { wt (mg) }\end{array}$ & $\begin{array}{l}\text { No. } \\
(\%)\end{array}$ \\
\hline \multicolumn{8}{|l|}{ Exp. $2 a$} \\
\hline 111 & 10 & 18 & $33 \pm 10$ & $8(44)$ & 17 & $22 \pm 4$ & $2(12)$ \\
\hline 222 & 10 & 19 & $63 \pm 9$ & $13(68)$ & 16 & $49 \pm 11$ & $6(38)$ \\
\hline 333 & 10 & 20 & $90 \pm 12$ & $16(80)$ & 19 & $89 \pm 14$ & $13(68)$ \\
\hline 1000 & 10 & 16 & $114 \pm 14$ & $14(88)$ & 17 & $100 \pm 19$ & $12(71)$ \\
\hline \multicolumn{8}{|l|}{ Exp. $2 b$} \\
\hline 1000 & 5 & 5 & $13 \pm 3$ & $3(60)$ & 5 & $56 \pm 11$ & $2(40)$ \\
\hline 1000 & 10 & 5 & $81 \pm 10$ & $5(100)$ & 5 & $83 \pm 37$ & $3(60)$ \\
\hline 1000 & 15 & 15 & $91 \pm 15$ & $12(80)$ & 15 & $108 \pm 19$ & $11(73)$ \\
\hline 1000 & 20 & 15 & $68 \pm 11$ & $12(80)$ & 15 & $111 \pm 17$ & $10(67)$ \\
\hline 1000 & 25 & 10 & $77 \pm 19$ & $7(70)$ & 10 & $100 \pm 23$ & $6(60)$ \\
\hline
\end{tabular}




\section{Experiment 3: effects of IUDs and hormone treatment in intact mated female mice}

Although IUDs of the type used here interrupt pregnancy in this strain of mice (Martin \& Finn, 1970), it was possible that because they were inserted near the uterotubal junction they simply prevented passage of embryos or killed them in passing (Parr, 1969; Hurst, Jefferies, Eckstein \& Wheeler, 1977), and did not directly inhibit implantation or decidualization. Experiments were therefore carried out to check that the IUDs interrupted pregnancy when they were placed elsewhere in the uterus and actually inhibited oil-induced decidualization, and also to see if the doses of hormones used in ovariectomized mice (see Exp. 1) would suppress the antifertility effects of IUDs in mated animals. The intact female mice were rested for 2 weeks after insertion of the IUDs or sham operation and then placed with males. The day of finding a plug was called Day 1 of pregnancy. Some mated females received an intraluminal instillation of arachis oil at 14:00 h on Day 5 of pregnancy; all were killed on Day 7 and the numbers of implantation sites and deciduomata were noted.

The results (Table 3) show that the IUDs completely inhibited implantation whether inserted at the ovarian or the cervical end of the uterus. Treatment with exogenous progesterone (1 mg) or progesterone $(1 \mathrm{mg})$ plus oestrogen $(10 \mathrm{ng})$ failed to reverse the inhibition. The presence of an IUD at the ovarian end of the horn completely inhibited oil-induced decidualization and this inhibition was not prevented by treatment with progesterone on Days 3-6 of pregnancy.

Table 3. The effects of IUD position and hormone treatment $\left(\mathrm{P}=\right.$ progesterone, $\mathrm{Oe}_{2}=$ oestradiol) on implantation and decidualization in pregnant mice killed on Day 7

\begin{tabular}{|c|c|c|c|c|c|c|}
\hline \multirow[b]{2}{*}{$\begin{array}{l}\text { IUD } \\
\text { position }\end{array}$} & \multirow[b]{2}{*}{$\begin{array}{l}\text { Hormone } \\
\text { treatment }\end{array}$} & \multirow[b]{2}{*}{ Oil } & \multirow[b]{2}{*}{$\begin{array}{l}\text { No. of } \\
\text { mice }\end{array}$} & \multicolumn{3}{|c|}{ No. with implantations or deciduomata } \\
\hline & & & & $\begin{array}{l}\text { IUD } \\
\text { horn }\end{array}$ & $\begin{array}{r}\text { Cor } \\
\mathrm{h}\end{array}$ & $\begin{array}{l}\text { alateral } \\
(\%)\end{array}$ \\
\hline & & & & Implantations & $\operatorname{Imp}$ & atations \\
\hline None & None & - & 7 & 5 & 5 & (71) \\
\hline Ovarian & None & - & 18 & 0 & 13 & (72) \\
\hline Ovarian & P, Days 3-6 & - & 15 & 0 & 11 & (73) \\
\hline Cervical & None & - & 9 & 0 & 3 & (33) \\
\hline Cervical & P, Days 3-6 & - & 8 & 0 & 2 & (25) \\
\hline Cervical & P, Days 1-6 & - & 8 & 0 & 2 & (25) \\
\hline \multirow[t]{2}{*}{ Cervical } & $\mathrm{P}+\mathrm{Oe}_{2}$, Days 3-6 & - & 7 & $0^{*}$ & 3 & (43) \\
\hline & & & & Deciduomata & & \\
\hline None & None & $10 \mu \mathrm{l}$, Day 5 & 5 & 5 & 3 & $(60)$ \\
\hline Ovarian & None & $10 \mu 1$, Day 5 & 8 & 0 & 4 & (50) \\
\hline Ovarian & P, Days 3-6 & $10 \mu \mathrm{l}$, Day 5 & 5 & 0 & 3 & $(60)$ \\
\hline
\end{tabular}

* 1 large deciduoma at the IUD site.

\section{Experiment 4: effects of repeated oestrogen priming}

In the period of rest following IUD insertion, ovariectomized animals experienced only one artificial period of 'oestrus' induced by priming whereas the intact mice had undergone repeated oestrous cycles before being mated. To determine if this difference was critical, ovariectomized mice with or without IUDs were primed once (see Exp. 1), or repeatedly ( 3 daily injections of $100 \mathrm{ng}$ oestradiol-17\% once a week for 3 weeks starting the week of ovariectomy). All were then sensitized with progesterone $(1 \mathrm{mg})$ and oestrogen $(10 \mathrm{ng})$ for 4 days. In this experiment the instilled oil, given on the 3rd day of the progesterone + oestrogen injections contained colloidal carbon. The animals were anaesthetized $15 \mathrm{~min}$ before autopsy and given an intravenous injection of $0.25 \mathrm{ml}$ of a $1 \%$ solution of Pontamine Sky blue in $0.15 \mathrm{M}-\mathrm{NaCl}$. After dissection and weighing, the uteri were fixed in Bouin's fluid and cleared in benzyl benzoate (Orsini, 1962), 
before sectioning, to show how much instilled oil was retained and its relationship to decidualized areas of the uterus.

The results (Table 4) show that in mice primed once, the IUDs slightly reduced the number of positive decidual responses induced by oil ( $71 \%$ compared with $82 \%$ ) but increased the mean weight of the decidual tissue. Repeated priming increased the number and size of the decidual responses induced by oil in uteri without IUDs, but also greatly increased the effectiveness of the IUD in inhibiting the decidual response (33\% compared with $88 \%$ ). In these animals the IUDs significantly reduced both the number of positive responses induced by oil and the mean decidual weight. Clearly the continuation of cyclic oestrogenic stimulation was a major factor in determining the effectiveness of an IUD at the time of decidual induction.

Table 4. The effects of repeated priming with oestrogen on decidual responses away from the site of IUD insertion or oil instillation in mouse uteri with and without IUDs

\begin{tabular}{|c|c|c|c|c|c|c|c|}
\hline \multirow[b]{3}{*}{$\begin{array}{l}\text { Priming } \\
\text { treatment }\end{array}$} & \multirow[b]{3}{*}{$\begin{array}{l}\text { IUD } \\
\text { position }\end{array}$} & \multirow[b]{3}{*}{$\begin{array}{l}\text { No. of } \\
\text { mice }\end{array}$} & \multirow{3}{*}{$\begin{array}{c}\text { Mean } \pm \text { s.e.m. } \\
\text { wt of deciduomata } \\
\text { (mg) }\end{array}$} & \multicolumn{4}{|c|}{ Number of uteri } \\
\hline & & & & \multicolumn{2}{|c|}{ With deciduomata } & \multicolumn{2}{|c|}{ Without deciduomata } \\
\hline & & & & $\begin{array}{l}\text { With } \\
\text { oil }\end{array}$ & $\begin{array}{l}\text { Without } \\
\text { oil }\end{array}$ & $\begin{array}{l}\text { With } \\
\text { oil }\end{array}$ & $\begin{array}{c}\text { Without } \\
\text { oil }\end{array}$ \\
\hline Single & None & 11 & $109 \pm 13$ & 9 & 0 & 2 & 0 \\
\hline Single & Ovarian & 17 & $143 \pm 17$ & 12 & 0 & 1 & 4 \\
\hline Repeated & None & 17 & $160 \pm 20$ & 15 & 0 & 2 & 0 \\
\hline Repeated & Ovarian & 24 & $60 \pm 9$ & 8 & 0 & 1 & 15 \\
\hline
\end{tabular}

Examination of cleared uteri without IUDs (Pl. 1, Fig. 1) showed that deciduomata usually formed as a 'string of beads', each containing a small droplet of oil at its centre. Retention of oil was not a consequence of decidualization since animals treated with progesterone alone and instilled with oil showed a similar distribution of oil droplets $44 \mathrm{~h}$ later, although there was no decidualization (Pl. 1, Fig. 2). In mice primed once, instilled oil was retained in most IUDcontaining uteri, but instead of being distributed as separate droplets it was present as continuous cylinders which were mostly associated with continuous 'sausage-shaped' decidua (Pl. 1, Fig. 3). In mice primed repeatedly, instilled oil had disappeared from most IUD-bearing uteri (Pl. 1, Fig. 4) and none of these showed positive decidual responses. In the few uteri in this group that showed decidualization oil was present in every case. In no group were decidua observed that did not contain some oil at their centre. The most likely explanation of these observations is that oil must be retained for a considerable time to elicit a full decidual response, and that transient exposure to oil does not trigger the reaction.

The frequency of occurrence of uteri with oil but without deciduomata did not vary significantly between groups, suggesting that the inhibitory effects of the IUD were due solely to loss of intraluminal oil and not to loss of uterine sensitivity to retained oil. However, none of the IUD-bearing uteri showed spontaneous decidualization without oil: this suggests that in these circumstances the IUDs also reduce uterine sensitivity.

\section{Experiment 5: effects of repeated oestrogen priming on uterine leucocytosis}

Ovariectomized mice with IUDs were primed and treated with progesterone and oestrogen as in Exp. 4 but were killed at 11:00 h on the 3rd day of hormone treatment. Uterine epithelial morphology was evaluated and leucocytes were counted in sections from each IUD-containing horn. The counts were extremely variable within groups and are therefore presented as frequency histograms in Text-fig. 1 for comparison with counts from the IUD-bearing uteri from onceprimed but otherwise untreated ovariectomized mice, and from Day- 5 pregnant mice. 
In untreated ovariectomized mice most leucocytes were infiltrating the epithelium and few were free in the lumen. Of 16 uteri only 3 had epithelial leucocyte counts of less than 10. Treatment of once-primed mice with oestrogen and progesterone reduced the numbers of epithelial leucocytes (possibly by stimulating migration to the lumen, since luminal counts increased), increasing the number of uteri with counts of $<10$ epithelial leucocytes to 18 out of 24: 9 of these uteri showed signs of spontaneous decidualization with stromal oedema and alignment of the antimesometrial subepithelial stromal cells (Pl. 2, Figs 5 and 6; see also Finn \& McLaren, 1967). These specimens had luminal leucocyte counts ranging from 0 to 200 or more. Signs of decidualization were not observed in uteri with epithelial leucocyte counts $>10$, irrespective of luminal counts. The failure of decidualization is therefore associated with large numbers of leucocytes infiltrating the epithelium whereas the number in the lumen seems to be unimportant. In uteri with low epithelial leucocyte counts epithelial morphology was of the 'pillow type' (Martin \& Finn, 1978) which resembles the normal progestational type but is always associated with a failure of progestational closure of the lumen (Martin \& Finn, 1978). In mice primed repeatedly and treated with oestrogen and progesterone, all uteri had high epithelial leucocyte counts. The distribution of epithelial and luminal counts in this group resembled that of pregnant animals. In all cases the epithelium was grossly abnormal (Pl. 2, Fig. 7).

\title{
EXPLANATION OF PLATES
}

\begin{abstract}
PLATE 1
Mouse uteri cleared in benzyl benzoate to show decidual responses (swollen dark areas) and intraluminal oil (black areas). The site of the IUD and oil instillation is at the top of each figure. Figs 1, 3 and 4 show only the instilled horns; Fig. 2 shows the instilled and uninstilled horns.

Fig. 1. Uteri from mice given progesterone and oestrogen after repeated priming with oestrogen and instilled with oil $44 \mathrm{~h}$ before autopsy. Five show positive decidual responses and one a negative response. All contain intraluminal oil. $\times 2.5$.

Fig. 2. Uteri from once-primed mice given only progesterone and instilled with oil $44 \mathrm{~h}$ before autopsy. None show decidualization but all contain intraluminal oil. In one uterus the oil is distributed bilaterally. $\times 2 \cdot 5$.

Fig. 3. IUD-bearing uteri from mice given progesterone and oestrogen after priming once and instilled with oil $44 \mathrm{~h}$ before autopsy. All show positive decidual responses remote from the IUD site. In four uteri there are massive 'sausage-shaped' decidua. All the uteri contain continuous stretches of oil. In one uterus there is little decidualization despite massive retention of oil. $\times 2.5$.
\end{abstract}

Fig. 4. IUD-bearing uteri from mice given progesterone and oestrogen after repeated priming and instilled with oil $44 \mathrm{~h}$ before autopsy. Only two uteri contain oil and only one shows decidualization away from the IUD site. $\times 2 \cdot 5$.

\section{PLATE 2}

Figs 5 and 6. Transverse sections through the mid-regions of the IUD-bearing (Fig. 6) and contralateral (Fig. 5) uterine horns of a mouse primed once and killed on the 3rd day of treatment with progesterone and oestrogen. The IUD horn (Fig. 6) shows early stages of decidualization with stromal oedema and alignment of stromal cells. The lumen contains cell debris and leucocytes. The epithelium is free of leucocytes but is abnormal with a surface raised into pillow-like bulges, swollen nuclei and cytoplasmic basophilia. The contralateral horn (Fig. 5) is normal in appearance. $\times 200$.

Fig. 7. Transverse section through the mid-region of the IUD-bearing uterine horn of a mouse primed repeatedly and killed on the 3 rd day of treatment with progesterone and oestrogen. The lumen and luminal epithelium contain many leucocytes. The epithelium is grossly abnormal with swollen nuclei with enlarged nucleoli and cytoplasmic basophilia. $\times 200$. 


\section{PLATE 1}
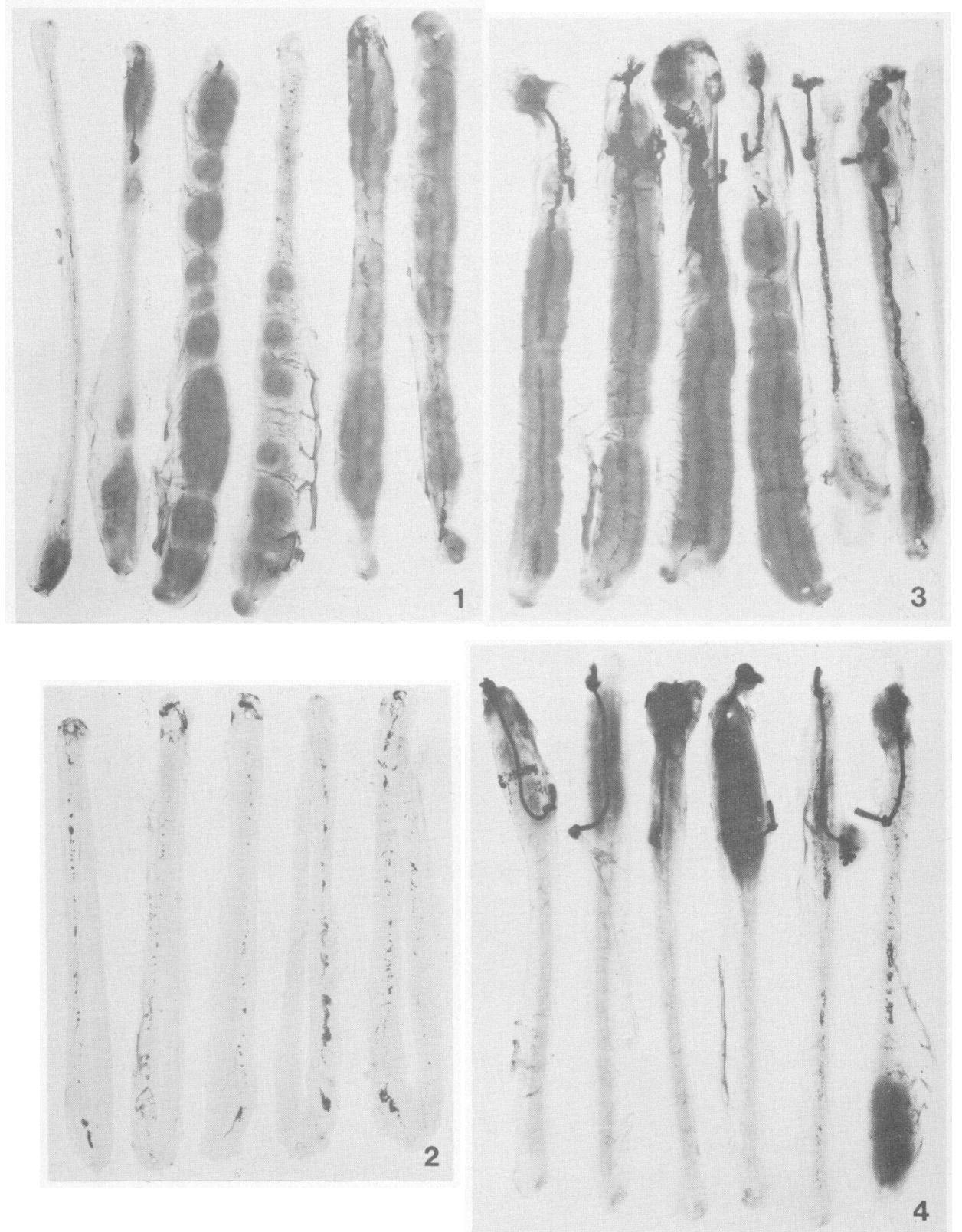

(Facing p. 130) 


\section{PLATE 2}

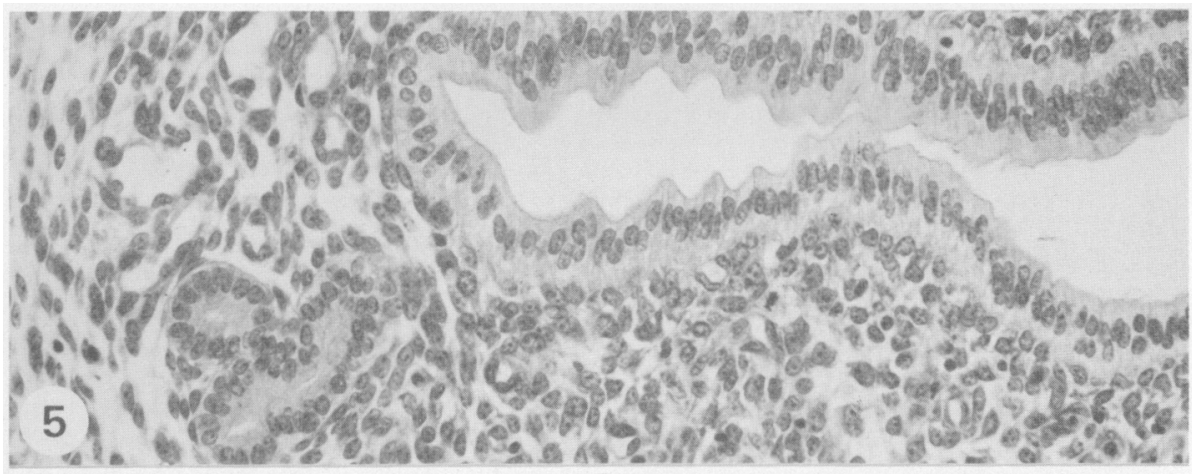
1.9. a d

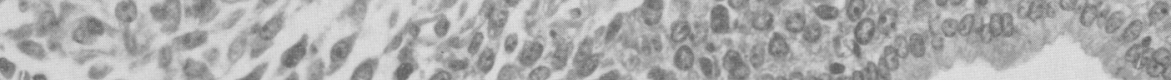

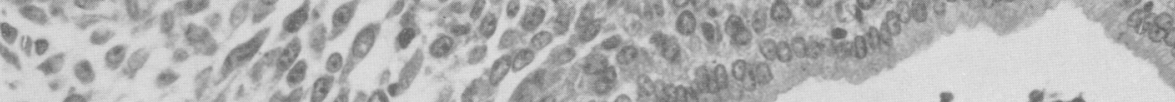

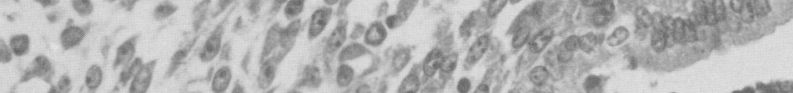

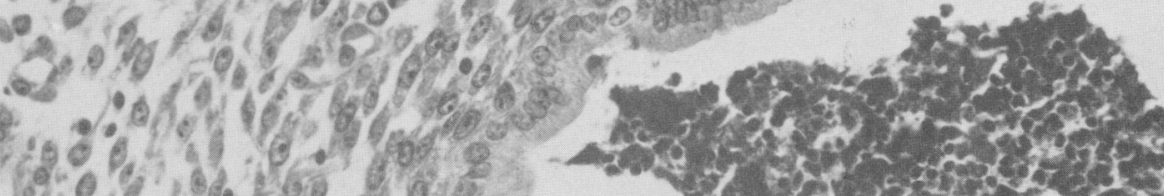

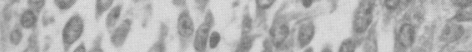
6.

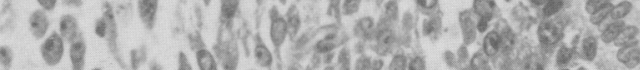

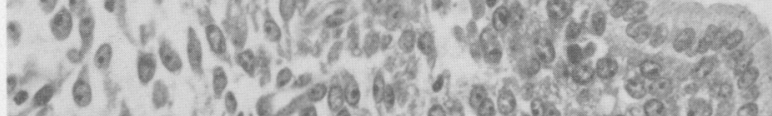

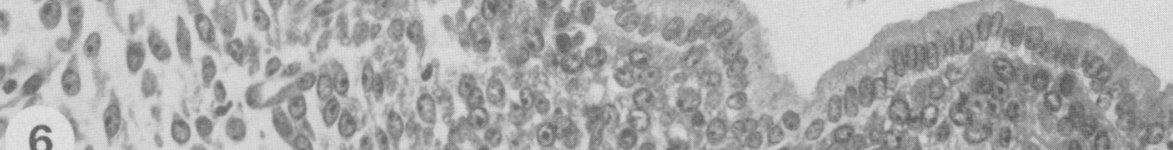

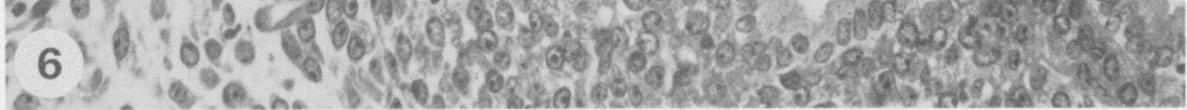

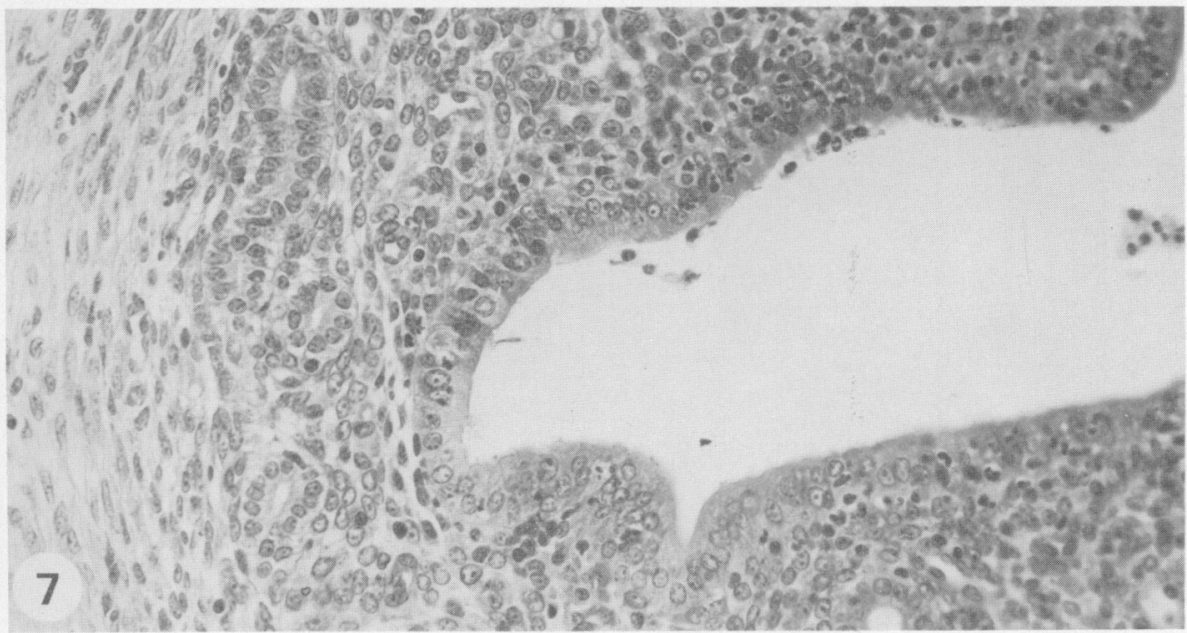




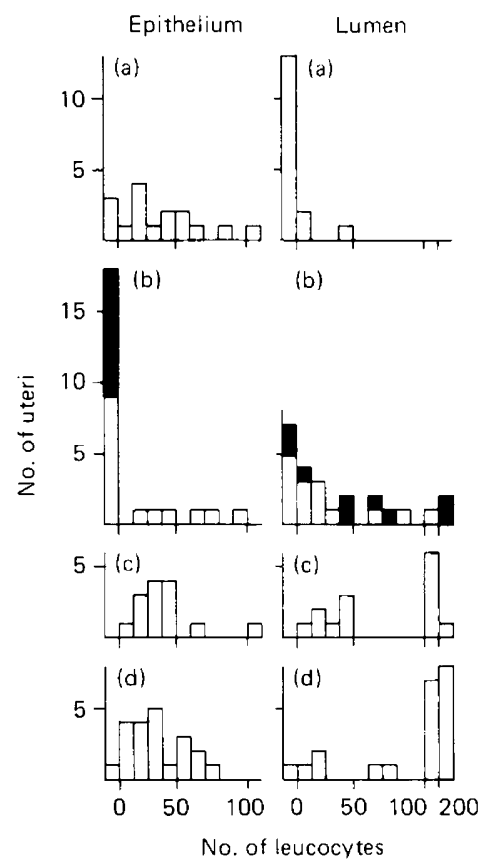

Text-fig. 1. Frequency histograms showing the distribution of leucocytes infiltrating the epithelium (left) and free in the lumen (right) of mouse uteri (mid-region) after various treatments. (a) Mice primed with oestrogen once after insertion of the IUD and killed 5 days later without further hormone treatment. (b) Mice primed and killed as in (a) but receiving $1 \mathrm{mg}$ progesterone $+10 \mathrm{ng}$ oestradiol on the day of autopsy and 2 days previously. The solid parts of the bars are counts from uteri showing early decidualization. (c) Mice treated with progesterone and oestrogen as in (b) but primed repeatedly after insertion of the IUD. (d) Pregnant mice mated not less than 14 days after IUD insertion and killed on Day 5 of pregnancy.

\section{Discussion}

Our results show that, depending on the endocrine status of an animal, an IUD can (1) itself induce a decidual cell reaction, (2) have no effect on the reaction, or (3) can prevent the occurrence of the reaction after the instillation of oil. The first conclusion contrasts with earlier results from intact mated rats and mice which consistently demonstrated inhibition. It seems likely that the occurrence of oestrous cycles before mating ensures inhibition of the decidual cell reaction, i.c. the periodic stimulation of the uterus by oestrogen alters the activity of the IUD from deciduogenic to anti-deciduogenic.

Unilateral uterine silk sutures induce unilateral sterility in rats, but most workers have found they induce bilateral sterility in mice. This appears to be due to the effective continuity of the uterine lumina between the two horns in most strains studied (Doyle \& Margolis, 1966; Marston \& Kelly, 1969a, b). We have consistently found unilateral silk threads to induce bilateral sterility (Martin \& Finn, 1970), epithelial leucocytosis and epithelial abnormalities (Martin \& Finn, 1978) in a minority of mice of our strain. Of 56 mated animals each with an IUD at the ovarian end of one uterine horn, $38(68 \%)$ were pregnant in the contralateral horn although none was pregnant in the IUD horn (Exp. 3; Martin \& Finn, 1970). The difference between our results and those of other workers partly stems from differences in positioning of the IUD; we place them at the ovarian tip rather than in the middle third of the uterine horn. A higher proportion of mice in our strain showed bilateral sterility when IUDs were placed near the cervix, but even then the sterility was not complete ( 32 animals mated; 0 pregnant in the IUD-bearing horn, $10(31 \%)$ 
pregnant in the contralateral horn). Thus a true strain difference is involved. This appears to result from peculiarities in the anatomy of the cervico-vaginal junction which we have discussed elsewhere (Martin \& Finn, 1978).

Increased uterine leucocytosis has been a consistent finding in studies of the IUD. Our results indicate that it is the number of leucocytes infiltrating the epithelium which determines whether or not a decidual reaction occurs; the number free in the lumen is not critical and substances secreted into the lumen by leucocytes are probably not important in inhibiting decidualization. Uterine luminal epithelial cells are joined at their apices by junctional complexes and leucocytes could prevent cells fulfilling their function of transducing the decidual stimulus (Finn \& Martin. 1974) simply by physically disrupting cell to cell continuity.

It is not clear why repeated oestrogenic stimulation should exacerbate leucocytic infiltration of the luminal epithelium. Parr, Schaedler \& Hirsch (1967) showed that leucocytosis of the rat uterus away from the IUD site resulted from bacterial infection. Short-term treatment with oestrogen causes a rapid disappearance of leucocytes from the mouse uterus (Martin \& Finn, 1978). Repetitive suppression of leucocytosis by oestrogen may therefore result in a build-up of infections which in turn induce increased leucocytosis when oestrogen is withdrawn.

The other factor which affected decidual response in the present studies was the degree of retention of instilled oil. In pregnant mice at the time of implantation, the uterine lumen closes and the opposed epithelial surfaces come into apposition with interdigitation of their microvilli. This reaction can be induced in ovariectomized mice by progesterone treatment (Martin, Finn \& Carter, 1970), and is prevented by the presence of an IUD (Martin \& Finn, 1970, 1978). Abnormalities in uterine closure could account for the patterns of oil retention seen in the IUDbearing uteri. In control uteri with normal full-length closure most of the instilled oil is expelled rapidly, leaving only small droplets behind (Martin, 1979). In mice treated with progesterone, closure is inhibited most near the IUD and least near the cervix (Martin \& Finn, 1978). Absence of closure near the IUD would allow oil to remain in the lumen, while closure near the cervix would prevent oil loss to the vagina, thus explaining the massive retention of oil in some IUDbearing uteri. Complete loss of oil from the IUD-bearing uteri of repeatedly primed mice could occur because of the failure of closure along the length of the uterus. Although premature loss of instilled oil would account for the anti-deciduogenic effects of IUDs in our experiments, the restriction of IUD-induced decidualization to uteri with low epithelial leucocyte counts suggests that those with high counts were insensitive to a decidua-inducing stimulus. Experiments with uteri ligated to prevent oil loss are required to examine this point.

Since decidualization occurs in conditions in which closure is prevented, closure is not essential to decidual differentiation. However, the disruption of closure would probably be sufficient to prevent blastocyst attachment and implantation. The mechanisms leading to luminal closure remain obscure. Closure is always accompanied by morphological differentiation of the epithelium (Martin et al., 1970) and is sometimes assumed to result from it (Finn \& Porter, 1975). However, the myometrium may also play a role. Circular muscle tone appears to be increased in progesterone-treated mice (Martin, 1979) and IUDs could interfere with this.

The mechanisms whereby IUDs induce decidualization in remote regions of the uterus are unknown. Leucocytes and debris were sometimes, but not always, present in the lumen at the site of decidualization. There was no evidence of gross damage to any uterine tissues. Spontaneous decidualization occurs in the vitamin E-deficient rat (Evans, 1928) but there are no reports of its occurrence in mice. In mice decidualization can be induced by trauma or the instillation of oil (Finn. 1965), mast-cell factors (Humphrey \& Martin, 1968) and air containing $\mathrm{CO}_{2}$ (Hetherington. 1968). Traumatic induction requires only pretreatment with progesterone whereas 'non-traumatic' instillations require pretreatment with progesterone plus oestrogen. There is evidence that the oestrogen is required for some crucial epithelial function. Since IUD-induced decidualization only occurred in mice given progesterone and oestrogen. the inducers are probably substances released into the uterine lumen which act via the same pathways as those involved in the induction of decidualization byioidientifica.com at 04/26/2023 09:01:15AM 
We are grateful to Gail Trinder for her expert histology service and to Lorna Lee for extensive technical help.

\section{References}

Bartke, A. (1968) Effect of an IUD on implantation and the decidual reaction in different strains of mice. $J$. Reprod. Fert. 15, 185-190.

Brown-Grant, K. (1969) Effect of an IUCD on an endometrial response to steroid hormones in the rat. J. Reprod. Fert. 18, 475-480.

Doyle, L.L. \& Margolis, A.J. (1966) The effect of IUFB on reproduction in mice. J. Reprod. Fert. 11, 27-36.

Evans, H.M. (1928) Spontaneous deciduomata in pseudopregnancy with low vitamin E. $A m$. J. Physiol. 85, 149-153.

Finn, C.A. (1965) Oestrogen and the decidual cell reaction of implantation in mice. $J$. Endocr. 32, 223229.

Finn, C.A. \& Martin, L. (1969) Hormone secretion during early pregnancy in the mouse. $J$. Endocr. 45, $57-65$.

Finn, C.A. \& Martin, L. (1972) Endocrine control of the timing of endometrial sensitivity to a decidual stimulus. Biol. Reprod. 7, 82-86.

Finn, C.A. \& Martin, L. (1974) Control of implantation. J. Reprod. Fert. 39, 195-206.

Finn, C.A. \& McLaren, A. (1967) A study of the early stages of implantation in mice. $J$. Reprod. Fert. 13, 259-267.

Finn, C.A. \& Porter, D.G. (1975) The Uterus. Elek Science, London.

Hetherington, C.M. (1968) The development of deciduomata induced by two non-traumatic methods in the mouse. J. Reprod. Fert. 17, 391-393.

Humphrey, K.N. \& Martin, L. (1968) The attempted induction of deciduomata in mice with mast cell, capillary permeability and tissue inflammatory factors. J. Endocr. 42, 129.

Hurst, P.R., Jefferies, K., Eckstein, P. \& Wheeler, A.G. (1977) Intrauterine degeneration of embryos in IUDbearing mice. J. Reprod. Fert. 50, 187-189.

Kar, A.B., Goswami, A., Kamboj, V.P. \& Chowdhury, S.R. (1964) Effect of a foreign body on the response of the uterus of ovariectomized mice to oestrogen. Steroids 4, 159-175.

Margolis, A.J. \& Doyle, L.L. (1964) Intrauterine foreign body. II. Inhibition of decidual response in the rat. Fert. Steril. 15, 607-617.
Marston, J.H. \& Kelly, W.A. (1969a) The time and site of contraceptive action of an intrauterine device in the mouse. J. Endocr. 43, 83-93.

Marston, J.H. \& Kelly, W.A. (1969b) The effect of uterine anastomosis on the action of an intra-uterine device in the rat. J. Endocr. 43, 95-103.

Martin, L. (1977) Decidualization and ovum-implantation in spayed mice treated with oestriol. J. Endocr. 72, $181-185$.

Martin, L. (1979) Early cellular changes and circular muscle contraction associated with the induction of decidualization by intraluminal oil in mice. $J$. Reprod. Fert. 55, 135-139.

Martin, L. \& Finn, C. A. (1970) The effects of an intrauterine device on uterine cell division and epithelial morphology during early pregnancy in the mouse. $J$. Endocr. 48, 347-354.

Martin, L. \& Finn, C.A. (1978) The effects of an intrauterine device on uterine cell division and epithelial morphology in ovariectomized mice treated with oestrogen and progesterone. J. Endocr. 78, 417-425.

Martin, L., Finn, C.A. \& Carter, J. (1970) Effects of progesterone and oestradiol-17 $\beta$ on the luminal epithelium of the mouse uterus. J. Reprod. Fert. 21, 461-469.

Martin, L., Finn, C.A. \& Trinder, G. (1973a) Hyper trophy and hyperplasia in the mouse uterus after oestrogen treatment: an autoradiographic study. $J$. Endocr. 56, 133-144.

Martin, L., Finn, C.A. \& Trinder, G. (1973b) DNA synthesis in the endometrium of progesterone-treated mice. J. Endocr. 56, 303-309.

Orsini, M.W. (1962) Technique of preparation, study and photography of benzyl-benzoate cleared material for embryological studies. J. Reprod. Fert. 3, 283-287.

Parr, E.L. (1969) Intrauterine foreign bodies: a toxic effect of leucocyte extracts on rat morulae in vitro. Biol. Reprod. 1, 1-9.

Parr, E.L., Schaedler, R.N. \& Hirsch, J.C. (1967) The relationship of polymorphonuclear leucocytes to infertility in uteri containing foreign bodies. $J$. exp. Med. 126, 523-540. 